\title{
Principles of New Developmentalism
}

\author{
Princípios do Novo Desenvolvimentismo
}

LUIZ CARLOS BRESSER-PEREIRA*

These principles proposed by Luiz Carlos Bresser-Pereira were originally presented and discussed at the $4^{\text {th }}$ International Workshop on New Developmentalism, São Paulo, July 26, 2019, held by the Center of Studies of New Developmentalism of the São Paulo Business School of the Getulio Vargas Foundation.

New Developmentalism is a school of economic thought that has a theoretical body and a set of economic policy proposals; it should not be confused with developmental economic systems. It is focused primarily on middle-income countries, but understands the developed economies need a similar approach. The antecedents of its development macroeconomics are on the Classical Developmentalism and Post-Keynesian Economics, while its political economy, on the Regulation School and Marx.

New Developmentalism may be defined by the following principles:

1. New Developmentalism originates from the classical political economy, Keynesian economics, classical institutionalism, classical developmentalism and the regulation school; it adopts primordially the empirical or historical-deductive method which searches to generalize from the regularities and tendency observed in reality; it relies on the most successful national experiences of economic development; it is critical of the neoclassical and the Austrian schools of thought not only because they give to the market roles that it cannot perform, but also because it adopts the hypothetical-deductive method - a method appropriate to the methodological sciences as mathematics and econometrics, not to substantive sciences as economics and biology.

\section{POLITICAL ECONOMY}

\footnotetext{
* Luiz Carlos Bresser-Pereira is Professor Emeritus of Fundação Getulio Vargas - FGV, São Paulo/SP, Brasil E-mail: bresserpereira@gmail.com; Orcid https://orcid.org/0000-0001-8679-0557.
} 
2. A capitalist society is a national society that originates from the political construction of a nation, the formation of a state, the occupation of a territory and the realization of the industrial revolution; when this historical process is completed this society, we may say that the nation-state just formed completed its capitalist revolution and is ready to grow in a sustained way.

3. The two main institutions that coordinate a capitalist society are the modern state and the market; the state in law system and the organization that guarantees it; the market is insuperable institution in coordinating competitive economic systems.

4. A capitalist economic system is developmental or liberal; it is liberal when it seeks to coordinate the economy only through the market; it is developmental when the state intervenes moderately in the economy.

5. We observe that, historically, the main objective of the nation-states is economic development - an economic process of capital accumulation and productive sophistication that increases the productivity and the income per capita and improves the standards of living.

6. Economic development turns into human development when, besides improving the standards of living, advances in the realization of the political objectives that modern societies defined for themselves - two procedural objectives (national autonomy and democracy) and five, final objectives: security, individual freedom, economic development, social justice and protection of the environment.

7. Economic development requires an autonomous nation-state and a developmental class coalition bringing together the business leaders, workers and civil society organizations, mediated by the government; a nation-state which capable of competing with the other nation-states at the same time that it cooperates with them.

\section{ECONOMICS}

8. Economic development depends on private investment and public investment; the latter depends on public savings; private investment depends on the entrepreneur's expected rate of profit (the expected rate of profit minus the interest rate);

9. The expected rate of profit depends not only on the existence of demand but also to the access to this demand, domestic or foreign; when the exchange rate remains overvalued cyclically in the long-term due to a non-neutralized Dutch disease and/or a high level interest rate adopted by the central banks, either to attract foreign capitals hoping to grow with foreign savings, and/or to control inflation, the companies utilizing the best technology available in the world will not be competitive and they will not invest; 
10. In coordinating the economy, the market is supposed to coordinate its competitive industries, while state is supposed:

a) to coordinate the non-competitive sectors of the economy; this is particularly relevant in the case of infrastructure (energy production and distribution, transport, logistics and communication), but also applies to the pharmaceutical industry and the financial sector;

b) to pursue a strategic industrial policy that is not limited to the protection of the infant industry, but also aims to encourage technological innovation through partnerships between private companies and the public sector, similar to what was done in Brazil with Embraer;

c) to adopt an active macroeconomic policy that ensures that the five macroeconomic prices (profit rate, interest rate, exchange rate, wage rate and inflation rate) are "right" or balanced - something that the market is unable to do.

11. The level of interest rates tends to be high in developing countries due

a) to high and chronic public deficits and current account deficits, which reflect a high preference for immediate consumption;

b) to two usual policies (using the exchange rate as a nominal anchor to control inflation and to grow with "foreign savings", i.e., current account deficit and the ensuing external indebtedness) which are mistaken policies because require a high interest rate to attract capitals, which do not add to domestic savings but replace them as they make companies uncompetitive and encourage consumption.

12. The exchange rate in developing countries tends to be cyclical and overvalued in the long-term (for several years between financial crises that close a cycle and open another) and the current account tends to show a deficit while the exchange rate is overvalued; this chronic overvaluation is due

a) to the practice of a high level of interest rates referred in 11 (b);

b) to the failure in adopting capital controls to avoid excessive foreign capital inflows;

c) to a non-neutralized Dutch disease;

\section{POLICIES}

13. The macroeconomic policy (fiscal, monetary, and exchange rate policy) should

a) keep balanced or stable the fiscal account, the government just adopting an expansionary fiscal policy countercyclically;

b) keep balanced the current account or showing a surplus when the country has the Dutch disease; the countries should only show current ac- 
count deficit when it is growing very fast and the marginal propensity to consumption falls so that the rate of substitution of foreign for domestic savings falls;

c) maintain satisfactory the rate of profit in the more sophisticated sectors of the economy (mainly industrial sector);

d) maintain the level of the basic interest rate (around which the central bank carries out its monetary policy) floating around the level of the international interest rate adjusted by the country risk;

e) maintain a competitive exchange rate, that stimulates exports and avoids that the domestic demand "leaks" unnecessarily abroad on the form of imports of goods and services that the country is capable of producing efficiently;

f) keep the rate of wages rising in line with the increase of productivity;

g) maintain the inflation rate low by rejecting all types of price indexation, and making use of fiscal and monetary policy a broad set of price stabilization instruments other than just the interest rate.

14. To neutralize the Dutch disease, it is necessary to create a variable tax on the export of commodities, or import tariffs on manufactured goods that compensate the disadvantage represented by the appreciated exchange; this is a second best alternative because it neutralizes the Dutch disease only in relation to the domestic market, but that many countries have adopted intuitively when they had as the main objective to industrialize.

15. The reduction of inequality should be sought through a progressive tax system, increased social expenditures aimed at establishing the welfare state (not its destruction), and the increase of the minimum wage provided that it does not conflict with a satisfying profit rate in the more sophisticated industries. Taxes should primarily burden rentiers' incomes (dividends, interest and rents).

To be a new-developmentalist the economist does not need to agree with these fifteen principles, but with most of them. New Developmentalism will be all the more creative and will better guide the economic development and catching up of developing countries as more variety of ideas exists.

Luiz Carlos Bresser-Pereira wrote this document which counted with the contribution of André Nassif, Carmem Feijó, Cristina Helena Pinto Mello, Eliane Cristina de Araújo, Felipe Quintas, Fernando Ferrari Filho, Jan Priewe, José Luis Oreiro, Luiz Fernando de Paula, Marcus Ianoni, Nelson Marconi, Ramón Garcia Fernandez e Robert Guttmann. 